\title{
Hyperhomocysteinaemia: risk of retinal vascular occlusion
}

G.H. Yaghoubi, ${ }^{1}$ F. Madarshahian ${ }^{2}$ and M. Mosavi ${ }^{3}$

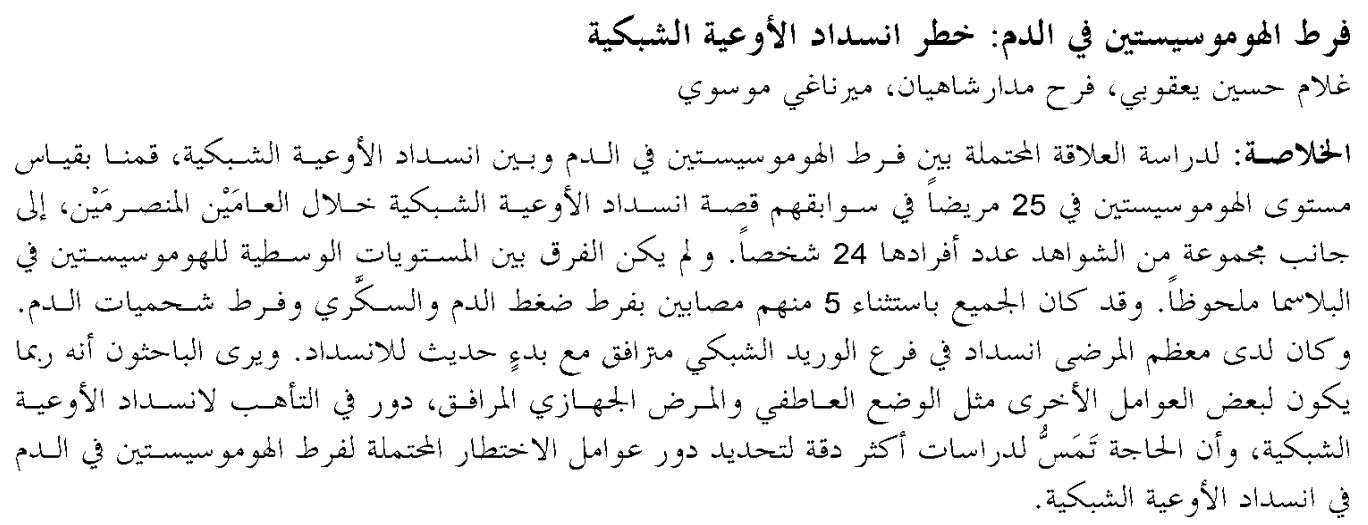

ABSTRACT To investigate the possible relationship between hyperhomocysteinaemia and retinal vascular occlusion, we measured plasma homocysteine levels in 25 patients with a history of retinal vascular occlusion in the previous 2 years and in a control group of 24 . The difference in mean plasma homocysteine levels was not statistically significant. All except 5 of the cases had hypertension, diabetes mellitus or hyperlipidaemia. Most of the patients had branch retinal vein occlusion associated with recent onset of occlusion. Factors such as emotional status and associated systemic disease may play a role in predisposition of retinal vascular occlusion, so more-precise studies are needed to determine the possible risk factors of hyperhomocysteinaemia in retinal vascular occlusion.

\section{Hyperhomocystéinémie : risque d'occlusion vasculaire rétinienne}

RÉSUMÉ Afin d'examiner le lien possible entre l'hyperhomocystéinémie et l'occlusion vasculaire rétinienne, nous avons mesuré les taux d'homocystéine plasmatique chez 25 patients ayant fait une occlusion vasculaire rétinienne dans les deux années précédentes et dans un groupe témoin de 24 sujets. La différence des taux moyens d'homocystéine plasmatique n'était pas statistiquement significative. Tous les cas sauf cinq avaient une hypertension, un diabète sucré ou une hyperlipidémie. La plupart des patients avaient une occlusion de branche veineuse rétinienne associée à la survenue récente de l'occlusion. Des facteurs tels que l'état émotionnel et une maladie systémique associée peuvent jouer un rôle dans la prédisposition à l'occlusion vasculaire rétinienne. Des études plus précises sont donc nécessaires pour déterminer les facteurs de risque possibles de l'hyperhomocystéinémie dans l'occlusion vasculaire rétinienne.

${ }^{1}$ Department of Ophthalmology, Valiaser Hospital; ${ }^{2}$ Nursing College, Birjand Medical University, Birjand, Islamic Republic of Iran.

${ }^{3}$ Department of Ophthalmology, Mashhad University of Medical Science, Mashhad, Islamic Republic of Iran.

Received: 09/05/03; accepted: 20/10/03

لبحلة الصحية لشرق المثتوسط، منظمة الصحة العلمية، البحلد العاشر، العدذان ع-0، ع • • 


\section{Introduction}

Thrombophilia is an increased tendency to thrombosis which is sustained by an ongoing stimulus to thrombogenesis or by a defect in the normal anticoagulant or fibrinolytic mechanism. Genetic factors are important in thrombophilia since thrombosis can be familial and may be associated with congenital deficiencies of the protein $\mathrm{C}$ anticoagulant pathway, antithrombin III, heparin cofactor II or plasminogen. Although the relationship between hyperhomocysteinaemia and vascular occlusion is still uncertain, it is of increasing interest that less severe abnormalities of methionine metabolism may predispose to the development of premature vascular disease. Endothelial dysfunction is also a factor in the complex changes that occur in vessel walls in hyperhomocysteinaemia [1,2]. Retinal vein occlusion is a major cause of retinal vascular disease, second only to diabetic retinopathy [3]. Branch retinal vein occlusion (BRVO) and central retinal vein occlusion (CRVO) are the 2 major categories, both having a similar potential for loss of vision owing to complications causing macular oedema and neovascularization [4].

Considering the various uncertainties regarding the many possible risk factors for retinal vascular occlusion, this study was carried out to measure plasma homocysteine levels in patients diagnosed with retinal vascular occlusion and to compare the results with those of a control group to determine whether elevated homocysteine level is a risk factor in retinal vascular occlusion.

\section{Methods}

We carried out a retrospective study of 25 out of 31 patients with retinal vein occlusion who consecutively attended the eye clinic of Valiasr Hospital, a teaching hospital of Birjand Medical University, from May 2002 to December 2002. Diagnosis of retinal vascular occlusion was based on clinical findings of ophthalmoscopic examination (well-demarcated haemorrhage and oedema along obstructed retinal vein). In uncertain cases fluorescein angiography was also done. A matched control group of 24 individuals was selected from people attending the clinic but who had no signs of retinal vascular occlusion, glaucoma, uveitis or intraocular surgery/trauma.

All participants completed a checklist consisting of questions covering demographic data, current disease, disease history, eye trauma and consumption of drugs. Then the fasting plasma homocysteine levels of the patients who had agreed to participate and had given informed consent was measured. Patients were classified into 3 major categories of retinal vascular occlusion based on their first episode: CRVO, BRVO (macular or main branch) or central retinal artery occlusion. The cases and controls were matched for age and sex.

Fasting blood samples were collected in heparinized tubes from all participants. After immediate centrifugation, the resultant plasma samples were packed in an icebox and sent to the Pars Laboratory, Tehran to measure plasma homocysteine levels.

Analysis of data was done with respect to presence/absence of a systemic condition, sex, age group and mean plasma homocysteine as independent variables and retinal vein occlusion as the dependent variable.

\section{Results}

Of the 25 patients with retinal vascular occlusion, 14 had BRVO and 10 had CRVO. Central retinal artery occlusion was diagnosed in a single case. 
The onset of occlusion in 6 patients occurred within the previous 6 months (1-6 months); in the rest, occlusion had occurred more than 6 months previously (730 months).

The characteristics of all participants, both cases and controls, are shown in Tables 1 and 2. A more detailed comparison of related disease in both cases and controls is shown in Table 3. The mean total plasma homocysteine level was 15.0 (SD, 5.7) $\mu \mathrm{mol} / \mathrm{L}$ for patients with retinal vascular occlusion and 13.4 (SD 4.1) $\mu \mathrm{mol} / \mathrm{L}$ for the control group (Table 4). The mean level was $13.8 \mu \mathrm{mol} / \mathrm{L}$ in patients with BRVO and $16.5 \mu \mathrm{mol} / \mathrm{L}$ in patients with CRVO. Of the 25 patients, 20 had at least 1 associated disease (diabetes mellitus, hypertension, hyperlipidaemia, asthma) for which they were under treatment by their primary care doctor and were taking medication. In the control group, these conditions were present in only 4 of the 24. The independent $t$-test showed no significant difference between plasma homocysteine levels for cases and controls $(P$ $=0.24$ ).

The Mann-Whitney test showed no significant difference between homocysteine levels in patients with BRVO and those with CRVO $(P=0.33)$. The Fisher test showed that there was also no significant difference in homocysteine level between hypertensive patients with BRVO and those with CRVO $(P=0.67)$.

Visual acuity in all BRVO cases was 1.1 or better in comparison to hand motion perception, and 0.1 in CRVO patients.

\section{Discussion}

In this study, we found no significant clinical association between hyperhomocysteinaemia and retinal vascular occlusion, although mean plasma homocysteine levels were higher in patients than in the control group. Most of these patients had at least 1 associated systemic disease.

The sample size in our study was small and both the patients and those in the control group were hospital-based subjects. This was a single blind study, in which the results may have been affected by the type of retinal vascular occlusion (most of the cases had BRVO). Our findings are similar to those of Larsson et al., who also reported that hyperhomocysteinaemia was not an important factor in the etiology of CRVO [5].

There may be different pathogeneses for the different kinds of retinal vascular occlusion. If there is an association with the location of the vascular obstruction, this finding may be related to increasing plasma homocysteine levels, or more probably to homodynamic change or local vascular insult. This was discussed by Cahill et al., who considered CRVO to be associated with similar risk factors to retinal arterial occlusive disease. Local factors such as atherosclerotic retinal arteries compressing the retinal vein at arteriovenous crossings may be more important in the etiology of BRVO [6].

Hyreh et al. recommended that, apart from routine medical evaluation, an extensive and expensive workup for systemic disease is unwarranted in the vast majority of patients with retinal vein occlusion [7]. This raises 2 points. First, is vascular occlusion pathophysiologically different in different organs? If so, we can consider that the attributing factors must be produced in greater amounts or elevated in larger vessels of the affected organ. Second, how much time has passed between the occurrence of vascular occlusion and the measurement of the plasma homocysteine level, because homocysteine levels are affected by many factors (diet, emotional state, etc.).

لبحلة الصحية لشرق المثتو سط، منظمة الصحة العالمية، البجلد العاشر، العددان ع-0، ع • • 
$636 \quad$ La Revue de Santé de la Méditerranée orientale, Vol. 10, № 4/5, 2004

\begin{tabular}{|c|c|c|c|c|c|c|c|}
\hline Patient & $\begin{array}{c}\text { Age } \\
\text { (years) }\end{array}$ & Sex & Eye & $\begin{array}{l}\text { Type of } \\
\text { occlusion }\end{array}$ & $\begin{array}{l}\text { Associated } \\
\text { disease }\end{array}$ & Addiction & $\begin{array}{c}\text { Plasma } \\
\text { homocysteine } \\
(\mu \mathrm{mol} / \mathrm{L})\end{array}$ \\
\hline 1 & 42 & Female & L & BRVO & HY & None & 6.6 \\
\hline 2 & 76 & Male & $\mathrm{R}$ & CRVO & HY & None & 25.0 \\
\hline 3 & 68 & Male & $\mathrm{R}$ & CRVO & HY & None & 11.9 \\
\hline 4 & 60 & Male & L & CRVO & HY & None & 16.8 \\
\hline 5 & 71 & Female & L & BRVOMB & None & None & 17.9 \\
\hline 6 & 48 & Female & $\mathrm{R}$ & CRAO & None & None & 17.4 \\
\hline 7 & 60 & Female & $\mathrm{R}$ & BRVO & HY, DI & None & 25.0 \\
\hline 8 & 66 & Female & $L$ & BRVO & $\mathrm{HY}$ & None & 18.0 \\
\hline 9 & 56 & Female & $L$ & BRVO & $\mathrm{HY}$ & None & 12.4 \\
\hline 10 & 68 & Female & $\mathrm{R}$ & CRVO & DI & None & 12.5 \\
\hline 11 & 45 & Male & L & BRVO & None & None & 14.2 \\
\hline 12 & 48 & Male & L & CRVO & DI, $\mathrm{HCH}$ & None & 13.0 \\
\hline 13 & 40 & Male & L & BRVOMB & $\mathrm{HY}, \mathrm{HCH}$ & None & 12.7 \\
\hline 14 & 38 & Female & $\mathrm{R}$ & BRVO & HY, DI & None & 14.6 \\
\hline 15 & 56 & Female & $\mathrm{R}$ & BRVO & $\mathrm{HCH}$ & None & 11.0 \\
\hline 16 & 60 & Female & $\mathrm{R}$ & BRVO & $\mathrm{HY}$ & None & 15.5 \\
\hline 17 & 60 & Female & L & BRVO & $\mathrm{HY}$ & None & 11.5 \\
\hline 18 & 63 & Female & $\mathrm{R}$ & BRVO & $\mathrm{HY}, \mathrm{HCH}$ & None & 12.6 \\
\hline 19 & 63 & Male & L & CRVO & AS & None & 18.0 \\
\hline 20 & 61 & Female & $\mathrm{R}$ & BRVO & $\mathrm{HCH}$ & None & 10.3 \\
\hline 21 & 65 & Female & L & CRVO & None & None & 9.2 \\
\hline 22 & 70 & Male & $\mathrm{R}$ & BRVO & HY & None & 10.5 \\
\hline 23 & 70 & Male & $\mathrm{R}$ & CRVO & $\mathrm{HCH}$ & None & 27.0 \\
\hline 24 & 80 & Male & L & CRVO & None & None & 10.5 \\
\hline 25 & 80 & Male & L & CRVO & HY & None & 21.0 \\
\hline
\end{tabular}

CRVO = central retinal vein occlusion.

$B R V O=$ branch retinal vein occlusion

$C R A O=$ central retinal artery occlusion.

$M B=$ macular branch.

$H Y=$ hypertension

$\mathrm{HCH}=$ hypercholesterolaemia .

$D I=$ diabetes.

$A S=$ asthma

Although our study did not find a significant difference in hyperhomocysteinaemia levels between the case and the control groups, Lahey et al. have reported that hypercoagulability plays a role in thrombus formation in patients with CRVO who are

بلملة الصحية لشرق المثتوسط، منظمة الصححة العلمية، المجلد العاشر، العددان ع-0، ع • •؟ 


\begin{tabular}{|c|c|c|c|c|c|}
\hline Participant & $\begin{array}{c}\text { Age } \\
\text { (years) }\end{array}$ & Sex & $\begin{array}{c}\text { Associated } \\
\text { disease }\end{array}$ & Addiction & $\begin{array}{c}\text { Plasma } \\
\text { homocysteine } \\
(\mu \mathrm{mol} / \mathrm{L})\end{array}$ \\
\hline 1 & 79 & Male & None & None & 7.0 \\
\hline 2 & 77 & Female & None & None & 16.9 \\
\hline 3 & 75 & Female & None & None & 11.7 \\
\hline 4 & 25 & Female & None & None & 7.1 \\
\hline 5 & 53 & Female & $\mathrm{HY}$ & None & 13.0 \\
\hline 6 & 61 & Female & DI & None & 15.4 \\
\hline 7 & 52 & Male & None & None & 21.0 \\
\hline 8 & 57 & Male & HY & None & 19.4 \\
\hline 9 & 47 & Male & None & None & 9.0 \\
\hline 10 & 65 & Female & None & Smoking & 10.2 \\
\hline 11 & 67 & Female & None & None & 11.8 \\
\hline 12 & 47 & Male & None & None & 17.6 \\
\hline 13 & 47 & Female & None & None & 7.3 \\
\hline 14 & 47 & Male & None & None & 14.0 \\
\hline 15 & 50 & Female & None & None & 11.8 \\
\hline 16 & 51 & Female & $\mathrm{HY}$ & None & 13.8 \\
\hline 17 & 60 & Male & None & None & 17.3 \\
\hline 18 & 65 & Female & None & None & 9.9 \\
\hline 19 & 70 & Male & None & None & 11.5 \\
\hline 20 & 70 & Male & None & None & 12.5 \\
\hline 21 & 74 & Male & None & None & 11.5 \\
\hline 22 & 76 & Male & None & None & 22.0 \\
\hline 23 & 80 & Female & None & None & 16.2 \\
\hline 24 & 85 & Male & None & None & 13.8 \\
\hline
\end{tabular}

$H Y=$ hypertension.

$D I=$ diabetes .

under 56 years old [8]. They concluded that hypercoagulability may play a part in the pathogenesis of CRVO, but the cause remains multifactorial, and laboratory tests alone cannot determine the cause in most patients. They recommended examining blood pressure, intraocular pressure, complete blood count, glucose level and a lipid panel in all patients with CRVO. When tests for these common risk factors for CRVO are negative, they would consider ordering selected tests in young patients with CRVO to rule out thrombophilia. Furthermore, in 2 other studies the authors describe sclerotic thickening of the central retinal artery that could easily compress the adjacent central

البحلة الصحية لشرق المتو سط، منظمة الصحة العالمية، البحلد العاشر، العلدان ع-0، ع • • 


\begin{tabular}{|c|c|c|c|c|}
\hline \multirow[t]{2}{*}{ Variable } & \multicolumn{2}{|c|}{ Cases $(n=25)$} & \multicolumn{2}{|c|}{ Controls $(n=24)$} \\
\hline & $\%$ & $\begin{array}{c}\text { Mean } \\
\text { homocysteine } \\
(\mu \mathrm{mol} / \mathrm{L})\end{array}$ & $\%$ & $\begin{array}{c}\text { Mean } \\
\text { homocysteine } \\
(\mu \mathrm{mol} / \mathrm{L})\end{array}$ \\
\hline Male sex & 44.0 & - & 50.0 & - \\
\hline Hypertension & 56.0 & 15.3 & 12.5 & 15.4 \\
\hline Hyperlipidaemia & 24.0 & 14.4 & 0.0 & - \\
\hline Diabetes mellitus & 16.0 & 16.2 & 4.2 & 15.4 \\
\hline Without disease & 16.0 & 13.8 & 83.3 & 12.4 \\
\hline
\end{tabular}

Mean age of cases and controls was 60.5 and 61.7 years respectively $(\mathrm{P}=0.77)$.

Mean homocysteine level in cases and controls was 15.0 and $13.4 \mu \mathrm{mol} / \mathrm{L}$ respectively $(\mathrm{P}=0.24)$.

retinal vein and begin the sequence that leads to thrombus formation. Therefore, hyperhomocysteinaemia may represent a "double hit" in the multifactorial pathogenesis of CRVO $[9,10]$.

Although many reports suggest hyperhomocysteinaemia is a risk factor for vascular occlusion, our study shows that it plays a less important role than systemic risk factors for retinal vascular occlusion.
Systemic hypertension was more common in cases than in control subjects. Also, most of the cases had at least 1 systemic disease (e.g. hypertension, diabetes, hyperlipidaemia). Therefore, hyperhomocysteinaemia may represent a coincidental association in the pathogenesis of retinal vascular occlusion. These paradoxical results not only demand repeating cohort studies with a larger sample size, they also

Table 4 Distribution of cases according to type of retinal vascular occlusion

\begin{tabular}{lccccc}
\hline $\begin{array}{l}\text { Type of } \\
\text { occlusion }\end{array}$ & $\begin{array}{c}\text { No. Diabetes } \\
\text { mellitus } \\
\text { No. }\end{array}$ & $\begin{array}{c}\text { Hyper- } \\
\text { tension } \\
\text { No. }\end{array}$ & $\begin{array}{c}\text { Hyper- } \\
\text { lipidaemia } \\
\text { No. }\end{array}$ & $\begin{array}{c}\text { Mean } \\
\text { homocysteine } \\
(\mu \text { mol/L) }\end{array}$ \\
\hline CRAO & 1 & 0 & 0 & 0 & 17.4 \\
CRVO & 10 & 2 & 4 & 2 & 16.5 \\
BRVO & 14 & 2 & 10 & 4 & 13.8 \\
Total & 25 & 4 & 14 & 6 & 15.5 \\
\hline
\end{tabular}

CRAO = central retinal artery occlusion

$C R V O=$ central retinal vein occlusion.

$B R V O=$ branch retinal vein occlusion

بلملة الصحية لشرق المتوسط، منظمة الصحة العلمية، المجلد العاشر، العلددان ع-0، ع • •؟ 
highlight the need to assess the preventive effects of lowering homocysteine levels on the recurrence of retinal vascular occlusion in cases compared to future attacks in control subjects.

\section{Acknowledgement}

We wish to thank our colleague Hydari Behroze for his valuable assistance.

\section{References}

1. Fermo I et al. Prevalence of moderate hyperhomocysteinaemia in a patients with early-onset venous and arterial occlusive disease. Annals of internal medicine, 1995, 123(10):747-53.

2. Faraci FM. Hyperhomocysteinemia: a million ways to lose control. Arteriosclerosis, thrombosis, and vascular biology, 2003, 23(3):371-3.

3. Blice JP, Brown GC. Retinal vascular occlusive disease. In: Spaide RF ed. Diseases of the retina and vitreous. Philadelphia, W.B. Saunders Company, 1999:116.

4. Clarkson JG. Central retinal vein occlusion. In: Ryan SJ. Retina. Singapore, CV Mosby, 2001:1368.

5. Larsson J, Hultberg B, Hillarp A. Hyperhomocysteinemia and the MTHFR C677T mutation in central retinal vein occlusion. Acta ophthalmologica scandinavica, 2000, 78(3):340-3.
6. Cahill $\mathrm{M}$ et al. Raised plasma homocysteine as a risk factor for retinal vascular disease. British journal of ophthalmology, 2000, 84(2):154-7.

7. Hayreh SS et al. Systemic diseases associated with various types of retinal vein occlusion. American journal of ophthalmology, 2001, 131(1):61-77.

8. Lahey JM et al. Laboratory evaluation of hypercoagulable states in patients with central retinal vein occlusion who are less than 56 years of age. Ophthalmology, 2002, 109(1):126-31.

9. Vine AK. Hyperhomocysteinemia: a new risk factor for central retinal vein occlusion. American journal of ophthalmology, 2000, 129(5):640-4.

10. Brown BA et al. Homocysteine: a risk factor for retinal venous occlusive disease. Ophthalmology, 2002, 109(2):287-90.

البحلة الصحية لشرق المثو سط، منظمة الصحة العالمية، البحلد العاشر، العددان ع-0، ع + • 